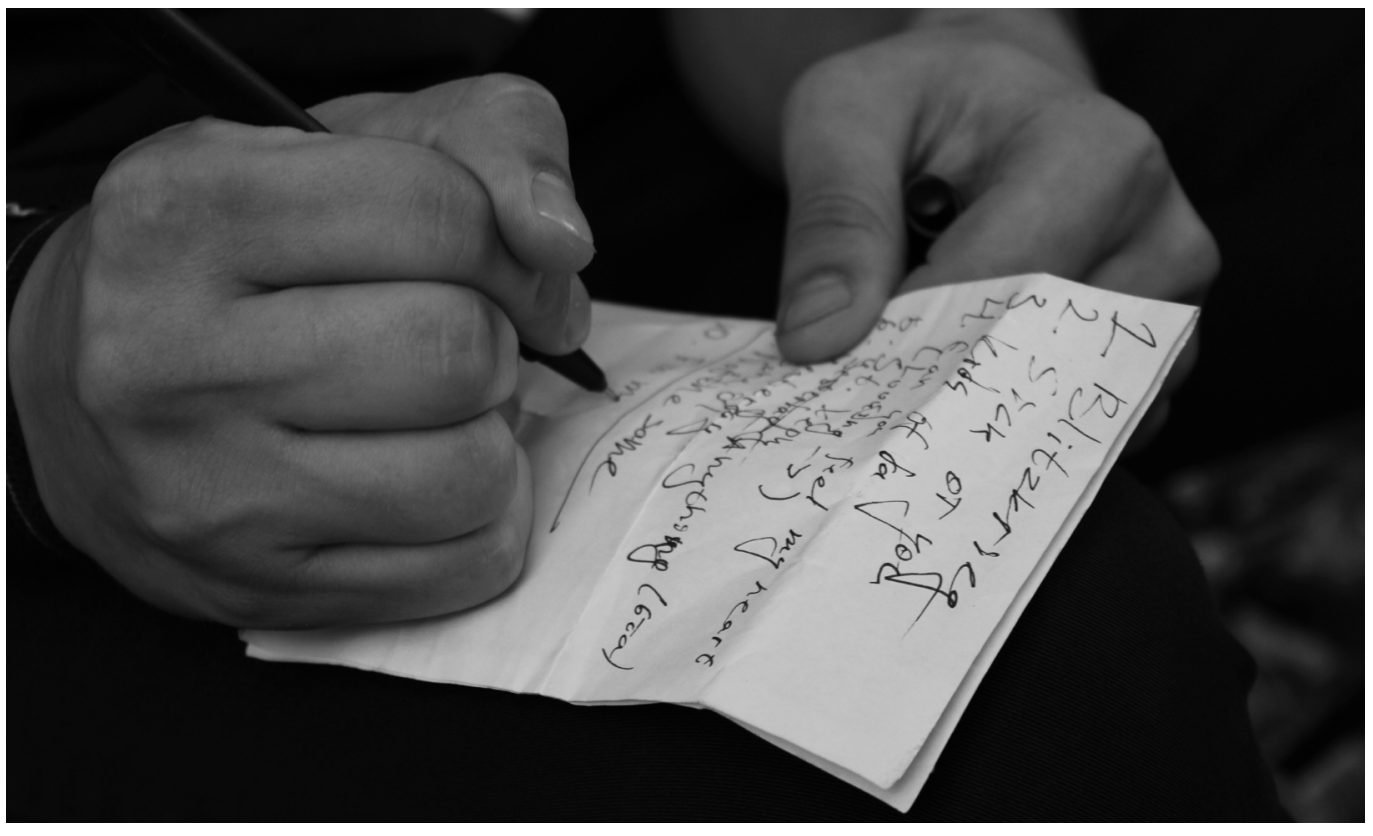

PC: @hmateeva (CC),

Flickr.com

\title{
The Effable Worker
}

\section{Ivan FRANCESCHINI}

Leftist intellectuals have long pondered whether it is possible to convey the experience of being working class in writing and other artistic forms. Does this still apply today, when humans from all walks of life are possessed by a violent desire to express themselves on social media? Does posing this question even make sense at a time when the working class has experienced a 'symbolic death' and the working-class subject belongs nowhere? To shed some light on these questions, this essay discusses three recent Italian memoirs that recount the work experiences of their authors. ocked in a shelter for the homeless on a weekend along with a few dozen vagrants, a young George Orwell was feeling the pangs of boredom. He had nothing to read, nothing to do, and could not even look outside since the windows were too high. He tried to listen to the general conversation, but found it left much to be desired:

There was nothing to talk about except the petty gossip of the road, the good and bad spikes, the charitable and uncharitable counties, the iniquities of the police and the Salvation Army. Tramps hardly ever get away from these subjects; they talk, as it were, nothing but shop. They have nothing worthy to be called conversation, because emptiness of belly leaves no speculation in their souls. The 
world is too much with them. Their next meal is never quite secure, and so they cannot think of anything except the next meal. (Orwell 2002a: 11)

The near impossibility for the poor and downtrodden to look beyond the most pressing need to survive made any artistic expression from members of the subaltern classes valuable to Orwell. When reviewing an autobiographical book by a working-class author a few years later, he did not equivocate:

Books like this, which come from genuine workers and present a genuinely working-class outlook, are exceedingly rare and correspondingly important. They are the voice of a normally silent multitude ... If all of them could get their thoughts on paper they would change the whole consciousness of our race. (Orwell 2002b: 34)

Yet, Orwell was fully aware of how hard it was for people on the lower rungs of the socioeconomic ladder, often deprived of a proper education, to find the right words to convey their experiencejust like one of his own acquaintances, a tramp who was trying to write his autobiography:

\section{He was quite young, but he had had a most interesting life which included, among other things, a jail-escape in America, and he could talk about it entrancingly. But as soon as he took a pen in his hand he became not only boring beyond measure but utterly unintel- ligible. (Orwell 2002b: 34)}

The problem, however, is one not only of intelligibility and style. When subalterns get to speak in their own voice, they often express views that not only are surprising to whomever is listening, but also turn out to be utterly disappointing to the scripted expectations. In the 1960s and 1970s, when Jacques Rancière began unearthing the writings of those French workers who managed to leave a trace of their views in popular publications before Marxist discourse came to insert itself into the voices of working-class protests, he found something unforeseen. Whereas he was expecting to discover a class-subject unified through a set of sociabilities and utopian religions, he found two distinct and separate realities. He uncovered, on the one hand, a chronicle of countless atomised struggles always confined to the particularity of the actors involved; on the other, there were workers' pamphlets and papers that expressed a working-class identity-just not the identity he was looking for:

[T] his assertion was completely tied to a denial of the identity imposed by Others. The workers spoke in order to say that they were not those Others, those 'barbarians' that bourgeois discourse denounced, and whose positive existence we subsequently sought to discover. And this speech, far from being rooted in the soil of utopian culture. showed an indifference towards, or rejection of, extravagance or utopian immorality. (Rancière 2019: 22)

The reality he brought to light was deeply unsettling-as disturbing as the realisation among leftist circles in recent years that working-class voters throughout the developed world have been rallying to far-right, xenophobic political movements.

Italian intellectuals have always been at the vanguard of this type of exploration of working-class identities. A few years before Ranciére embarked on his enterprise, Italian operaisti ('workerists') began mounting a critique of the bureaucratism of organised trade unions, arguing for the need to tap into the revolutionary spontaneity of fractions of the dominated classes not yet organised, especially those migrant workers who were leaving the south of the country in troves to find employment in the factories of the north (Keycheyan 2014: 80-85). A centrepiece of the Italian workerist approach was the 'workers' inquiry'-an attempt to analyse through sociological means the 'subjective factor' of how dominated classes experience the domination to which they are exposed. However, this approach had its own limitations. As Ottiero Ottieri wrote in his classic 1959 novel, Donnarumma all'assalto: 


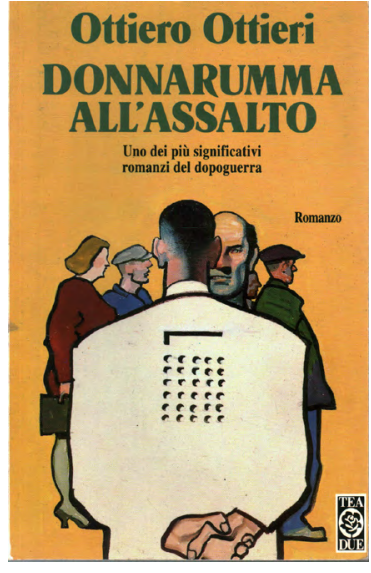

Donnarumma All'Assalto, Ottiero Ottieri, 1959

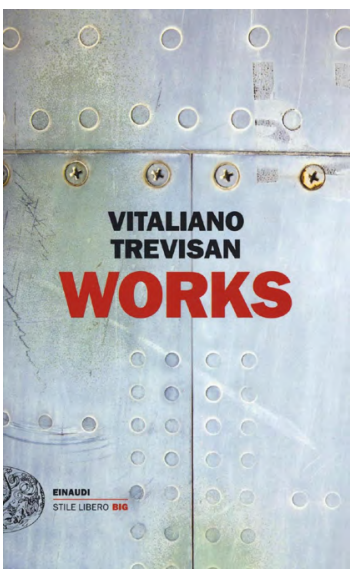

Works, Vitaliano Trevisan, 2016.
Sociology always looks for its method of investigation and pursues it. If I try to work at the presses, I am not them. If I interrogate them, they can lie. If I observe them, I can describe them but not understand them. If I put myself in their head, I can make up a wrong inner monologue. They should express themselves; and yet, from the moment when they express themselves, they betray or overcome that silence which is characteristic of the worker condition, which, perhaps, can only be inferred from indirect signs, from life outside the factory. (Ottieri 2004: 173)

Which brings us back to the original point made by Orwell about the silence of the poor and downtrodden, with an additional twist: even workers who manage to express themselves through the artistic form should be considered unreliable witnesses to the working-class condition, as their ability to convey meaning somehow separates them from their peers.

This additional layer of ineffability further adds to the enigma of the working class. But does this still apply today, in what Richard Seymour (2019: 16) calls the era of the 'twittering machine', when humans from all walks of life 'are, abruptly, scrip- turiens - possessed by a violent desire to write, incessantly'? Do these questions even make sense at a time when, as Cynthia Cruz $(2021: 6,9)$ has argued, the working class has experienced a 'symbolic death' and the working-class subject belongs nowhere, as 'a ghost, existing between worlds, a haunting'? Three recent Italian memoirs that recount the work experiences of their authors help shed some light on these questions.

\section{Works}

The first is Works, a 650-page memoir published in 2016 by the late Vitaliano Trevisan (born in 1960, he committed suicide on 7 January 2022). Even though the volume is entirely in Italian, the choice to give it an English title can be read as paradigmatic of the 'foreignness' of Italy's mondo del lavoro ('world of labour', an entirely Italian formulation used to refer to everything related to labour) as experienced by the author in the three decades between his first factory job in the mid-1970s and the moment he achieved success as a writer in the early 2000s-a time frame that coincides with the transformation of Italy's labour 
market from one in which job security was the rule to a wild arena dominated by precariousness and uncertainty.

The story begins with the teenage author asking his parents to buy him a bicycle only to be tricked by his father into working at a factory producing birdcages not far from his home, in a small town near Vicenza, in Italy's industrialised north. From that moment-although he later received a highschool diploma as a surveyor that should have paved the way for a lucrative career-Trevisan's work life became a rollercoaster with few highs and many lows. After some youthful experiences as a small-time drug dealer and a parenthesis in a prestigious architecture studio and some companies where he was assigned technical and managerial positions, he takes up odd jobs as diverse as construction worker, waiter, ice-cream seller, ink-cartridge recycler, tinsmith, street cleaner, and warehouse worker, until his final job as a night porter in a small-town hotel.

Looking back at these experiences when he is in his fifties and an established writer, Trevisan realises his life has been anything but linear:

\section{Thinking about my work history as a whole, I could very well say that it has been nothing but a long series of false starts, of roads taken without knowing well why, and all sooner or later abandoned. Despite this, at least from a certain point on, a sort of progression, more than a real career, began to take shape. Not a trajectory. Not even an arch. No curved lines in my life, but a broken one, the segments of which are linked to that diploma that I would have never wanted to receive, and which, before breaking up for good, gets to cover a period of almost fifteen years. Before that, only incoherent fragments, that do not lend themselves to be put in line. (p. 90)}

This incoherence is wilfully reflected in the style of the memoir, which, as the back cover unabashedly points out, reads like a 'classical jazz composition', which is nothing but a euphemism for the chaos of continuous digressions, flashes forward, and lengthy tangential footnotes that make up this book-a structure that reflects the author's declared antipathy for all editors, whom he considers the epitome of the 'industrialisation' of writing (p. 332, footnote).

If his experience of Italy's mondo del lavoro felt 'foreign' to Trevisan, this was because he set such precariousness and fragmentation against the model of his father, who spent his whole life as a policeman, as well as against the expectations of his mother. Although other family members appear only insofar as their actions affect the author's professional choices, they play fundamental roles. His father is the one who tricks the young Trevisan into the birdcage factory job when he demands money to buy a new bicycle, effectively kickstarting his working life; his mother is always nagging him, saying he should do something better with himself, subtly influencing his views and decisions; his older sister is a source of tension when she and her family take over the family house and then refuse to take Trevisan back in his time of need; and his ex-wife not only introduces the author to the secrets of the goldsmith profession, but also brings him to the verge of a breakdown, sending him running to Germany to take on a seasonal job as an ice-cream seller. It is his family, and in particular his father, which sets the invisible standards to which Trevisan compares himself and, unwillingly, finds himself wanting. In a poignant passage, these feelings of inadequacy come to the surface with full force:

\begin{abstract}
Why do I always find a job?, I was telling myself, Why don't they let me go adrift in peace? Become a hobo. One of the possibilities I was contemplating. Which I still contem plate now. Then I lack the courage. My father comes to mind, the policeman Arturo, and his uniform, always impeccable; and my grandfather, the dignity with which he wore his best clothes. Absurdities that always come back to me. The origin is a dress that one never takes off. (p. 532)
\end{abstract}

On a few occasions, the author comes close to achieving a stable job 'respectable' enough to gain his mother's approval, but then pulls back in horror at the idea of what this would entail on an existential level. Again, the not-so-implicit 
comparison is with how labour was experienced by many (most?) in the generation of his parents. For instance, in describing the moment when, at the age of 29, he is offered his first open-ended contract, Trevisan writes:

\begin{abstract}
Never really thought about retirement, and the idea of a permanent job, of undetermined length [in Italian, 'open-ended' is rendered as a tempo indeterminato], which means thirty-five-forty years in the same place, to do more or less the same thing, every day the same road to go and come back, the same people, etc, had always disturbed me, even though, at least in appearance, it was what I seemed to be always looking for, all the more desperately, and which now, perhaps, I had finally found. (p. 237)
\end{abstract}

It would not matter much to him that after more than 10 years in the labour market, he has managed to accumulate only one year of social security contributions-meaning he has almost always been employed in the informal economy-if it were not for his mother, who keeps bringing this up to criticise his life choices (p. 237). Similarly, when Trevisan attends a party at another company in which he is now pursuing a promising career and sees the bosses give some senior employees a commemorative plaque and a watch, he reacts with disdain. The patriarchal conception of the workplace as a 'big family' in which employers and employees take care of each other for the duration of their lives disgusts him:

Ah no!, I was telling myself, this doesn't suit me at all, I don't want to join any fucking big family. The one I have is enough, and I wouldn't be able to stand another one. If I am here, it is only because I must be. I work and you pay me, period. I don't give a fuck about your sons and grandsons. And if I ever found myself in the place of one of those senior employees, I thought, after over thirty years of work, seeing the plaque and the watch, I would most likely break those little arms of yours. Or maybe not, I also thought. because after thirty years in the same place. I too would be a senile old guy just like them. (p. 272)

It is easy to imagine how such contempt for a conception of il mondo del lavoro that places stability and predictability above any other consideration puts the author at odds not only with his parents, but also with many of his peers, fuelling his feelings of alienation. For Trevisan, work comes with no illusions regarding the nature of his relationship with his employers and the workplace: labouring is simply a way to make money to survive; there is no emotional attachment to it. For instance, when, much later in his career, he ends up working in a cooperative of Catholic imprint that arranges social work for recovering drug addicts, his supervisor points out that he is doing everything well, but without passion. This leads the author to muse that 'demanding a contagious enthusiasm for the job from me, that I even have faith in it, was wasted time' (p. 588).

The rejection, however, is not one-sided. Throughout the book, Trevisan repeatedly expresses dismay at his discovery that, even when he takes on blue-collar jobs that bring him to share the same hardships as his co-workers day in and day out and ends up developing feelings of camaraderie, he still feels like an outsider. For instance, when he joins a small tinsmith company comprising only a handful of people and spends his days climbing roofs along with them to fix gutters, he retains an uncomfortable sensation of being different in the eyes of his colleagues. Even though he shares every experience with his co-workersincluding almost falling from a roof-he realises they still treat him with kid gloves:

They feel, and I know, that I am not completely one of them, even if I do exactly everything more or less like them, and put my life in their hands without hesitation, with the same ease with which they put theirs in mine; and what, more than this, I thought, can make you a part of other people's lives?, and yours part of theirs, without any question. However, in spite of this, I could not avoid noticing how they still tended to give me a special treat- 
ment, to preserve me, in a certain way, from the dangers a bit more dangerous among those that can be found daily in the work experience of the tinsmith. (p. 433; Here the author quotes at length from an earlier story he wrote.)

What really sets Trevisan apart from his colleagues is his deep conviction-even in the many years before he manages to put a single line on paper-that writing is his true vocation and deliverance from il mondo del lavoro. Not knowing this, his co-workers simply think that, if the situation becomes unbearable, Trevisan's surveying diploma and skills allow him a way out-a luxury they do not have. At the same time, other idiosyncrasies make Trevisan stand out, such as his habit, at the beginning of every new job, of securing a copy of the national contract for his category and reading it carefully to know about his rights and duties (p. 520). While being generally apolitical in his approach to labour, he tries, as a warehouse worker, to bring to the attention of his co-workers the unfairness of some company policies. His only attempt at labour organising spectacularly backfires:

What the fuck was I thinking? Giving them a bit of class consciousness, what else? Class consciousness! I cannot believe I wrote this. It seems even more impossible that I thought this, and that I even believed in it. And still, it is it: I really thought so. A remnant of the Seventies perhaps, even though, during the Seventies, I had never believed those who busied themselves to instil in me that which I now wanted to instil in my workmates. And not only was I deluding myself that the endeavour itself was possible, but also that it could have been accomplished by me, and on top of that by me alone. (p. 556)

Once again, this failure triggers in him the feeling that he does not belong: 'It is destiny that I should never belong to anything, not even my class. It is they themselves who remind me of this. They accept me, but sooner or later point it out to me' (p. 529).
Even though Trevisan clearly resents this hybrid condition, his liminal position inoculates him against the misconceptions that dominate public discussion regarding the working class these days in Italy and beyond. In accounting for the criminal phenomenon of the morti bianche (the 'white deaths' due to the lack of workplace safety measures that are so common in Italy), he draws from his experience as a tinsmith in a tiny company in which the bosses share the same risks and workload as their workers to challenge the narrative about 'bad' employers and 'good' employees, pointing to how everyone plays a role in perpetuating this system. Then, he takes Italian intellectuals to task for their outdated conceptions of the working class. In a remarkable passage, he recounts how, in the mid-2000s, a famous Italian actor-who is never mentioned by name but is obviously The Great Beauty's Toni Servillo-offered to bring to the stage some of Trevisan's earliest writings based on his experiences as a warehouse worker. The experience is surreal. When the actor first reads the texts, he pictures the characters of three warehouse workers wearing blue overallsan archaic and cartoon-like image that Trevisan knows to be completely detached from the reality of the working class of today:

It was not easy to explain to him that these young 'workers', who refused the very idea of wearing anti-injury shoes provided by the company because they thought these shoes aesthetically sucked, who all went to tanning salons at least twice a week, who got into debt to buy a shitty Golf Tdi, or to go spend a couple of weeks in a Caribbean spermdrome [sic], who spent their weekends between discos and afterhours, often and willingly high on drugs, the great majority of whom professed themselves to be and voted for the Right, well, as I said, it was not easy to explain to $\mathrm{X}$ how these workers were completely foreign to that idea of his, which was so archaic that could have been considered part not of the archaeology of industry, but its palaeontology. (pp. 502-3) 


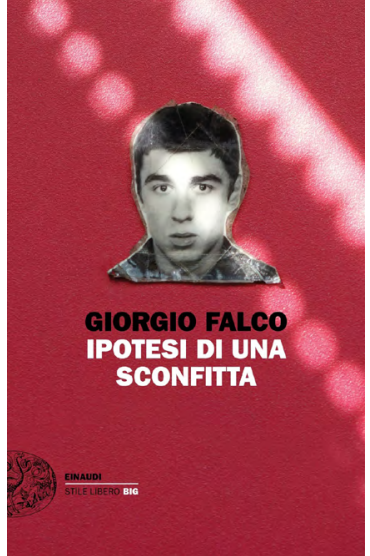

Ipotesi di una Sconfitta, Giorgio Falco, 2017

Trevisan takes this anecdote as being representative of the impermeable nature of the classes that characterises the present-a stark departure from the 1960s and 1970s, when 'it was fashionable among young members of the bourgeoise to deal with workers' (p. 504). Caustically, the author cites Adriano Sofri, a former leader of the Italian autonomist movement Lotta Continua, who said that the implicit rule for the youth of those years was 'to have sex with everyone, but marry only among ourselves', to say that today only the second half of that rule applies, leading to an estrangement so deep that many even claim social classes are now a thing of the past (p. 504). It is possible to argue that, despite Trevisan's largely apolitical language and stance, it is to recuperate the experience of a cohort whose very existence is denied, to dispel the illusion of the pervasive middle-classification of Italian society, that Trevisan put pen to paper. But what to make of a class that, even when you admit it exists and mingle in it, keeps you at bay?

\section{Hypothesis of a Defeat}

In his 2017 memoir Ipotesi di una sconfitta (Hypothesis of a Defeat), Giorgio Falco (born in 1967) covers a temporal frame similar to Trevis- an's. Starting with his decision to take a summer job in a lapel-pin factory when he is 17 , the book details how Falco's lack of interest in having a 'proper' career leads him to accept a series odd jobs, including conducting product placement surveys in grocery stores, driving foreigners around on business trips, selling door-to-door newspaper subscriptions, being a sales assistant in the fashion section of a mall, selling brooms and cleaning products, coaching a junior basketball team, working in a warehouse, and hanging cinema schedules. In the 2000s, the author moves from Milan to the Veneto region, where he finds a stable job with good benefits in the then booming telecommunications sector. Formally employed by a telecommunications company, he chooses to settle down in Rome and then return to Milan. However, as the sector quickly begins to unravel, he is confronted by increasingly exploitative practices in toxic workplaces. Only literary success eventually presents him with an escape from his plight.

By dedicating the first chapter to his father, who migrated from Sicily to Milan in the mid-1950s and immediately found a job as a bus driver with the city's public transportation company, Falco immediately sets a nostalgic tone for his memoir. He describes his father's morning routine, how he would get up every morning at 3.30 and was so afraid of being late he always set two alarms, leaving Falco with a habit of waking up suddenly between 3.20 am and 3.40 am that follows him to this day. Work ethics were of paramount importance to his father, and when, as a child, Falco told him how much he disliked the idea of getting a job, this irritated his father more than anything. Just as Trevisan associates the image of his father with that of his police uniform, Falco has fond memories of his father's bus driver's uniform:

I was afraid that, when he became a clerk, he could not wear the company uniform anymore. Instead, luckily for me, he had continued to wear one, just a bit more prestigious, with escutcheons and starlets on the shoulders of the jacket, as if it were the army. Ever since I was a child, I had loved the company uniform, to the point that I made it, pointlessly, the only costume that I would 
have wanted to wear at Carnival. I hated the Zorro, cowboy, or Indian American costumes. If I really had to follow the custom, I wanted to dress up like a company driver, or better. after my father's work successes [his promotion to clerk in charge of bus schedules], as head of the company. After all, I wanted to masquerade like my father: whether it was to demolish him with carnival derision or to absorb him until I was absorbed by him, I still don't know to this day. (p. 22)

More than once, Falco compares the decorum of his father and his colleagues with the shabbiness displayed by younger generations. As he watches footage of his father's retirement party, he comments on the dignified elegance of those men and contrasts it with the general sloppiness that is becoming the norm in every workplace. And, when, in the wake of his father's death, he visits what remains of the old bus depot and sees four drivers hired by the private company which has now taken over the service, he points out how none of them is wearing a uniform. Nothing can take away this dignity from his father, not even death: 'My father had been recomposed in the coffin, the shoes almost new, a black suit, the necktie, decorum as foundation of existence until the end, even beyond, in the endless decay of the following days' (p. 47).

Falco offers a pitiless assessment of Italy's mondo del lavoro at the turn of the century:

Here's the reason why we used to repeat and still repeat mondo del lavoro: we take for granted that it is a separate world, where every cruelty is possible exactly because it is work and not what takes a great portion of life, to the point that it becomes life itself. (p. 112)

Falco's work life over three decades leads him to this conclusion, beginning with his very first job, the two summer months he spends producing lapel-pins when he is seventeen. There, he toils with two other students for a miserable piece rate to produce pins featuring images of the rock stars of the day, plus one hour a day spent making pins of Jesus Christ and the Pope, which his boss forces them to produce for free, eating away their already meagre income. This leads him to question the hypocrisy of the Catholic Church, which was at the time ceaselessly working to erode communism while having nothing to say about capitalist exploitation:

While the other two students kept saying the pope or John Paul II, I only saw the man Karol Wojtyła. To me, the lapel pin of Karol Wojtyła looked like the counterfeit symbol of the freedom of the West, the pin of Karol Wojtyła was the simulacrum of economic and financial forces that deprecated the commu nist system but were replicating the same forms of exploitation in that shed that was so Italian, five hundred kilometres from Vatican City. The West was sucked in a shed. The West was only a shed. I could not directly blame Karol Wojtyła for my condition, there surely were intermediaries who engaged in speculation, starting with the boss. However, [pop star] Simon Le Bon allowed me to earn 5 liras, Jesus Christ 3 liras, Karol Wojtyła O liras. (p. 68)

Given he was a student and the uncle of one of his fellow student-workers was friends with the factory owner, Falco felt privileged: 'They were real workers, men and women, they packaged the merchandise that would later be exposed in the supermarkets; we were students, played at being workers, could deal with the futile' (p. 58). Working alongside 'real workers' for two months, he comes to admire them for their strength but also detests them for their docility, before realising that he has himself fallen head over feet into a Burawoyan 'making out game' of piece-rate work that makes him at least as pliant as they are. In moments of despair, he still has youthful hopes to which to cling: 'Despite my doubts about my ability to adapt to the world, I would never have spent my life in a shed nor produced lapel pins to pin on jackets; I would have gone to the university, I would have found a good job' (p. 65).

That is not to be: in the following years, he quickly drops out of university and begins the descent into the loop of odd jobs mentioned above. It is a momentous time in world history, but not for 
Falco. As the Berlin Wall falls in November 1989, he is going door to door selling subscriptions to a newspaper:

It was November, we were ringing bells, in Berlin they were making history. Friends of [my colleague] Chiara were there in the days when the Wall fell: they had left to live this event, be protagonists. Someone still had to ring bells, we could not all go to Berlin. And then to do what? To take a little piece of souvenir? Wasn't the concrete we had enough? (p. 136)

When the Soviet Union falls two years later and history supposedly reaches its end, he is puzzled to find himself subject to extreme exploitation as a warehouse worker at the mercy of two despotic bosses: 'The end of communism, an epochal turn. Media commentators argued that the world had really changed: I was working for two brothers from Abruzzo. They had hired me as a warehouse worker. I started at $9 \mathrm{am}$ and ended at $6 \mathrm{pm}$; break from $1 \mathrm{pm}$ to $2 \mathrm{pm}$; seven days a week' (p. 208). When he forgets to load a mannequin on a customer's car, they fire him on the spot and refuse to pay part of what he is owed.

Some of Falco's co-workers have a remarkable way to cope with being cut off from history. In the face of a depressing present and uncertain future, they take to embellishing their lives with unlikely stories of sexual exploits and proximity to Italy's elites. When he is working as a sales assistant in a mall, Falco befriends a very fat, middle-aged window-dresser whom he nicknames Olaf. Every day, Olaf spins tales enriched with considerable details about his liaisons with famous actresses and singers. While a factotum at the Milan Fair, Falco works alongside a man named Willie, who claims to live on a road where the resident who has 'the least money' is famous Italian TV host Mike Bongiorno. When another recent hire challenges this story, there is consternation among the crew:

Willie looked at him in astonishment. The new arrival had desecrated not so much the story of Mike Bongiorno, as a millenary tradition of orality; he ignored that a lie, especially if repeated, did not take away anything from the story nor from existence, it was not a retraction nor a downgrading of reality, but instead it enriched it. And, in addition, the stories told in the workplaces-those of Olaf, Willie, and the many others I met-could stand up to contradictions. (p. 206)

The author himself gives in to a leap of fantasy at one point, when he brings up with some friends the possibility of establishing an agency specialising in arranging depressing experiences-such as having your car break down on a highway in the middle of the Milanese hinterland-for the rich and powerful who have lost connection with reality.

Although his experiences in il mondo del lavoro are disastrous enough, it is when he enters the telecommunications industry that Falco truly falls from grace. After a few years in which he feels lucky to have found a stable job in a telecom company, he witnesses the descent of the industry into a hellscape of depersonalisation, 'bullshitisation', automation, and ultimate delocalisation. He begins with the task of activating SIM cards at a time when the market for mobile phones is booming; then is tasked with analysing the credit profile of prospective clients-a job that demands he repeatedly violate the privacy of individuals and companies to collect bank and other financial information with which to assign them a specific score. As his literary career begins to take off, he finds himself increasingly marginalised by his peers: 'The writer is expelled from the workplace by his own colleagues even before the managers. He is considered an alien body, one who is not like us. One who should not be there. If you are there, there is something wrong. You are a charlatan, a con, a traitor' (p. 291). In the wake of the publication of his first book, Falco is demoted to chase customers who miss a payment on their phone bills. As if this demotion were not enough, his position is later detached to a contractor where labour conditions are appalling and competition among colleagues cutthroat. As positions like his are soon moved to Romania, he is used to fill gaps in businesses the contractor has in the energy sector-first, to deal with the transfer of the utility contracts of the deceased, then, to face customers' complaints. 
In this new role, as he responds day in and day out to complaints from exasperated customers cheated by the company, he sees an even uglier face of capital. With his mental health quickly deteriorating, his only way to cope with the situation is to retreat within himself and appropriate a closet as his own office, so he does not have to see anybody. To evade all human contact, he does not drink any water, to avoid having to go to the toilet. One day he cannot resist, however, and ends up peeing in a plastic bottle. He has reached the bottom, and only his literary success saves him.

As an eyewitness to and a victim of the apocalyptic consequences of Italy's neoliberal revolution, Falco has unsparing words for three actors that, at least in theory, should have prevented such catastrophe: the trade unions, the Catholic Church, and workers themselves. While he is at the telecom company, Falco regularly attends union meetings, which he describes as perfunctory affairs. In so doing, he realises 'the trade union was not an instrument of struggle but of management of the transition' between two economic epochs, the first of which, coinciding with his youth, was a time 'when it seemed everything could last forever' (p. 280). As for the church, its guilt lies in its unholy alliance with capital in the bid to destroy communism, which eventually leads to it being swallowed by capitalism:

Unable to react to its own decline, the Catholic Church lived within the spell that it itself had created. Its words were lagging behind the common feeling, the faithful consumers were distracted by other things, by the opening of a new front, by a hypothetical liberation. And then the Church had started to use the same tools as its ally [capital]. For this reason, Karol Wojtyła behaved like a sportsman, one of those marathon runners who collapsed to the ground and kissed the earth after a victory, not like a man of religion. He had won his battle against communism, but in the process he had destroyed the Church, or worse, he had reduced it to irrelevance. (p. 283)
Yet, workers are the biggest disappointment for Falco. His colleagues in the telecom company are depicted simultaneously as victims and as perpetrators. When the author complains about the ventilation and heating conditions in their office-a common grudge that has already led to the hospitalisation of a colleague-his co-workers treat him as a nuisance. They are scared that, should they demand the company fix the heating system, the bosses might decide to save money by cutting their jobs: 'They were terrified of losing their job, they understood that it would have been easier to reemploy some detainee rather than them' (p. 286). Again, when Falco one day 'naively' asks his colleagues in the complaints department whether they feel any guilt about abetting the company in cheating the elderly with predatory contracts and other dirty tricks, they reply:

$$
\begin{aligned}
& \text { We don't care, we only do what they tell } \\
& \text { us to do, and quickly. They were not even } \\
& \text { Nazi-Fascists, they thought that they were } \\
& \text { saving themselves by refusing freedom, } \\
& \text { offering themselves up like robots, manpower } \\
& \text { for the lesser mechanical evil; during the short } \\
& \text { work breaks, they expressed a rage never } \\
& \text { addressed against the closest power-their } \\
& \text { own boss, the company-but always against a } \\
& \text { colleague at the same level. Had they received } \\
& \text { something more, a small benefit, an incen- } \\
& \text { tive, they would have become the most loyal } \\
& \text { supporter and executors of a dictatorship to } \\
& \text { which, albeit as extras, they already adhered } \\
& \text { to, almost for a natural question. (p. 298) }
\end{aligned}
$$

This Arendtian passage puts on full display the degeneration of Italy's working class, its atomisation, and its complicity in the perpetuation of a system that victimises those who are already marginalised-a 'permanent revolution of [the] free market that got everyone out of their responsibility, starting from the managers, and exempted from reaching any goal that was not money' (p. 295). A telling signal of this decay can be found in the fact that the new working class no longer has any affabulatory powers: 'There was no Olaf. Before I locked myself within the closet, in the company in the service industry I had not heard any stories 
that were worthy of my former workmates. To be sure, I didn't even want to listen: when I had done so, it had been depressing' (pp. 303-4).

Curiously, it is only while he is at the telecom company (before he is dispatched to the contractor) that Falco feels he is living up to the expectations of his now far-away father:

I should have taken a photo of myself, developed the film, and sent an image to my father, to show him that at the end he had won; even though we hadn't spoken in years, I lived the life that he had wanted so much for me. Employed in a big company, a small role but, in theory, with a little power. A role as a contemporary bureaucrat, just at a time when almost everybody considered bureaucracy the worst evil, the cause of the Italian decline. (p. 266)

His father has, perhaps, won, but this victory represents a defeat for the son-a defeat that will eventually become a total rout. It is this incompatibility and incommunicability between generations, the inability but also contemptuous unwillingness to live up to the expectations set by one's parents and grandparents, that is the crux of the contemporary working-class condition in Italy.

\section{Metres}

The third book was published in 2018 by Alberto Prunetti (born in 1973) under the title 108 metri (108 Metres)-another volume in Italian, but with an English subtitle: The New Working Class Hero. The book, a tiny 130 pages compared with the massive memoirs discussed above, details the author's experience as a migrant in and around Bristol in the United Kingdom, after he leaves his hometown to escape the miseries of Italy's mondo del lavoro. The son of a working-class family in Grosseto Province, Tuscany, he was supposed to follow in his father's footsteps, get a vocational education, and then become a skilled worker in Piombino's old steel plants. Instead, he chose to study at a scientific high school and then get a

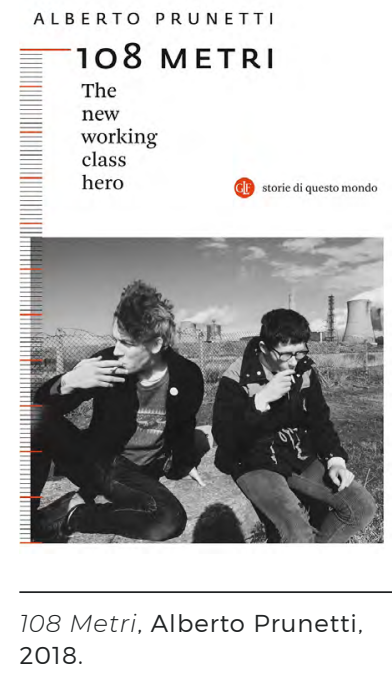

university degree-an education that set him apart from his peers. He later came to regret this choice, as a working-class kid like him who chose to stray from his path to the factory had only ' 1 -to-35 odds' to succeed: 'I was a provincial who knew nothing of the world. A failed promise of second-tier football and of the Maremman-Labronic working class. A rebel titan who had bet everything on the wrong horse: a university degree' (pp. 31-32). Curiously, we are told that he was set in this direction by a Jesuit collective, close to the circles of Catholic dissent, which in the 1970s began offering afternoon classes for workers' children and then opened a middle school in the area. Trained in the 'pedagogy of the oppressed', the educators at this institution used to send students to conduct surveys in workers' neighbourhoods and initiated Prunetti to the pleasures of reading and writinghabits tolerated by his father and strongly encouraged by his mother.

The generational break is, once again, a central theme of 108 Metres. The title of the book refers to Prunetti's hometown, the 'iron town' of Piombino, where 108-metre-long steel railway tracks were produced. His origins in this old Italian industrial centre are a source of pride for Prunetti, as is the fact his father has spent his whole life travelling around to do maintenance work for the steel factory. However, proud as he might be, the 
author is aware that the working-class legacy he takes pride in is now rapidly disappearing, and the world view that values manual work is vanishing along with it. In a poignant scene early in the book, Prunetti sketches the moment of his departure for England. When he is checking in for his flight, he discovers his luggage is much heavier than he thought. As he starts sorting through the contents, he realises that his father, Renato, has sneaked in some heavy plumbing tools, convinced his son might need them to find a job in England. While Prunetti removes them, a scene ensues between his father and the airline staff:

The situation quickly degenerated, and Renato took it on me, as if it were my fault: 'You see, nobody wants the tools anymore ... they are afraid of sweating! They are! To them, working sucks! I wasn't putting it in the hands of Prince Charles, the hammer, eh! The screwdriver and pliers were for my own son, eh!' Renato was almost about to hammer the check-in counter, while I was holding him by one arm. Yay, we made a fool of ourselves again! I knew it would have been better not to let them come for what to them is a goodbye. Well, you had to understand my parents: they had slipped the tools of the trade in my bag for my survival at the beginning. You never know. Only, times had changed. We had been told that labour had dematerialised, we would never have to sweat again, we would never have to use our hands again. (p. 30)

As well as the physical tools of his trade, Prunetti's father leaves him a more important legacy: a set of 'ten commandments'-universal rules that apply 'wherever there is a working class' (pp. 38-39). These include:

Help one's colleagues. Go on strike. Don't kiss the bosses' asses. Don't be a scab. Don't be pitiless if you have to beat up someone. Don't take it too hard with Pisans, they are human beings too. Don't trust the moneyed. If someone who has studied calls you 'sir', stand with your ass to the wall.
While the tools must be left at the airport, these rules stick with the author for life.

Before his departure, Prunetti had been stuck in a loop of poorly paid informal jobs in the Italy of the early 1990s. During the summer, he cleaned stretches of beach, cooked in pizzerias, served in bars, or cut the grass in the garden of some rich family; in winter, he could find absolutely nothing. His university degree was worse than useless, and he was even advised to avoid mentioning his education in his CV. Once in England, he finds his first job in a pizzeria in Bristol owned by an Italian family, where he spends three months along with riffraff, hooligans, and troublemakers from all over the world. Although the author explicitly resorts to Robert Louis Stevenson's characters and imaginaries to narrate this workplace and his colleagues-for instance, the cook is an old sailor and drug addict named John Silver-the description of the frenzied rhythms of the workplace is more reminiscent of George Orwell's experiences in the kitchens of Paris in Down and Out in Paris and London (it comes as no surprise that the translation of 108 metri into English by Elena Pala is titled Down and Out in England and Italy). Prunetti details how he and his co-workers in the kitchen engage in small acts of resistance, such as pretending to work, tricking the boss into rummaging in garbage bins, and spreading rumours about the restaurant. It is, overall, a terrible experience: not only does he not learn a single word of English, but also he works seven days a week for less than the minimum wage, without days off or holiday pay, living in a room above the pizzeria for which money is deducted from his wage, while his employers keep up the pretence that they are all a 'big family'. It all ends after a surprise visit to the premises by labour inspectors, when the owners literally push Prunetti out of a window.

Prunetti then finds a job in a shopping mall through an agency. He spends the first day cleaning tables in the food court, forbidden to sit or speak for eight hours; then, already feeling miserable and useless, he is informed by the manager that the next day he will be assigned to 'the pariah of the shopping mall, the untouchables, the latrine operators' (p. 62). It is then he feels he has hit rock bottom: 'Even in the food court, it is no paradise 
... But there is always someone doing worse than you, under you. And that someone under, that was me' (pp. 62-63). In the toilet-cleaning crew, he meets a series of unlikely characters, like Brian, an enormously fat fellow who looks a bit like Pavarotti, wears a papillon, and has a secret technique to unclog a toilet with his bare hands; and Kate, an elderly Irish woman who was pushed out of her job by the manager due to her advanced age only to be replaced by Prunetti. Although Prunetti gets along with his new colleagues in the toilets and finally manages to improve his English, the shopping mall is a jungle where employees who take too many cigarette breaks or ask for too many leaves of absence are subjected to unceasing gossip and eventually mobbed out, with no solidarity from their colleagues. It is only fitting that the manager greets Prunetti with a ridiculous 'see you later, alligator', and insists that he replies with 'in a while, crocodile' (p. 72). After Brian is fired, Prunetti decides to leave.

He then ends up working as a kitchen hand in a holiday camp in Stonebridge. There, he prepares meals for hordes of adolescents, along with another crew of rabblerousers that includes Ian, a petty thief, Gerald, an old and dirty former radio actor who knows Shakespeare by heart, and Ross, the son of a miner whose family was left broken by the policies of Margaret Thatcher's government in the 1980s. Prunetti spends some time there, until he accidentally discovers that the roof of the kitchen staff's accommodation is asbestos, and he is overtaken by uncontrollable anger: 'The managers had slate, the teaching staff had wood covered by isolating plastic tape, and we, the scullions from the kitchen, had asbestos. But then it was us who were the shitty ones' (p. 102). He does not even have time to take countermeasures, as he and his troublemaking colleagues are fired in small groups or one by one, to avoid any resistance. From there, he moves to pick raspberries under a caporale along with immigrants from Eastern Europe-an experience that also does not last long, as Prunetti is not compliant enough. Finally, he finds employment in an Italian restaurant run by Turkish immigrants pretending to be from Naples, where his only job is to help in the kitchen and loudly speak a few words of Italian to deceive customers about the authenticity of the place. After he accidentally burns himself on the handle of the oven, he throws a fit of rage at the owners and customers and quits.

The author's return to Italy is melancholic. Back in his hometown, Prunetti is surprised to find a clear sky. An old worker tells him in tears that the steel factory has been shut, its ovens turned off after a century. The elderly man, a friend of his father, does not know what will happen to the factory: rumours are swirling that it will be bought by Chinese, Indians, or 'cowboys', or that the ovens will be dismantled and reassembled in Brazil, but no-one knows for sure. Meanwhile, 2,000 workers and their families have been left to fend for themselves, and the 108-metre railway track segments now serve only as an escape route for local youths who need to travel to other countries to eke out a living. The elderly worker has no illusion about the past or the present:

To be honest it was hard work. Some hurt
themselves, some died, some got sick. It was
the last bread but it was also the only one.
And now even that is gone. But it was still
better than the way they take the piss at you
young people to make you work for free. They
make you run like hamsters in a wheel. They
make you go round and round, maremma
cane, turning around like 'trained animals'.
(p. 123)

To compound the sadness of this decline, on Prunetti's arrival home, he discovers that his father is terminally ill-most likely a consequence of a lifetime of hard work.

The book has a nightmarish Lovecraftian undertone-a creative ploy to underline the unspeakable horrors that workers today face under capitalism. One night, when he is working in the Italian pizzeria, Prunetti finds a mysterious cephalopod-headed (and fish-smelling) totem hidden in a niche in the room where the waitresses change before their shift. He returns to look for it the next day, but it is gone. Similarly, while he is working at the mall, a nauseating stink of fish and rotting seaweed and a mysterious chant emerge from the underground levels. After following this trail of odours and sounds, he 
witnesses a ceremony in which his direct supervisor and the mall's upper management adore a bigger version of the same cephalopod-headed idol, which, in this case, is surrounded by some ex-votos, including a photo of Thatcher in the guise of a multi-armed Kali goddess. During the ceremony, the chant mutates from an invocation to Cthulhu to Prunetti's supervisor reciting Thatcher's maxim: 'There's no such a thing as society, there are only individuals' (p. 77). From then on, the author has nightmares about the mall as a giant medieval hellscape, with the managers playing the role of demons and the employees as the souls of the damned. Finally, the holiday camp where Prunetti works as a kitchen hand features a Victorian 'Cthul Manor', where a reclusive director lives apart from everyone else, fuelling rumours that he is a deformed monster (this chapter is aptly titled 'Cthul Limited Company').

Prunetti holds no illusions about the strength of today's working class in facing these unspeakable horrors. When he is employed by the shopping mall, he attempts to cheer up a disheartened Brian by showing him illustrations from an old magazine that depict a society turned on its head. As he does so, he imagines how that carnival in which workers and managers and customers swap roles would work in the mall, but then has a realisation: 'These white magic spells of mine did not transform reality. That magic required the strength of workers' solidarity. But the adversary was too strong an enemy, able to cast spells and charms' (p. 76). And still, Prunetti argues, the Lovecraftian entity that is Capital today can be overcome. After his encounter in the lower levels of the shopping mall, he has a dream in which the idol is defeated by a swarm of bees-the workers. The incident in the Turkish restaurant breaks the spell for good:

I stormed into the hall and began haranguing the astonished crowd of customers, a speech full of screams and insults, in a macaronic English made threatening by my pink palm perpetually extended. And I said that I would have written and told everything. I swore it on the body and blood of wounded, exploited, and humiliated workers. And once I took that oath, which annulled the feudal one that wanted me as a servant to Her Majesty on British soil, I found myself free from any curse. (p. 116)

What he finds in his hometown breaks his heart and makes him wonder whether the curse has really been lifted, but even though he acknowledges that he might not achieve success in his lifetime, he is now determined to fight the Entity through his writing:

Perhaps I wouldn't have lived long enough to witness the end of the Entity. However, I knew that that day would come, I knew I could make it happen faster. I had to write my story, the story of the working class [in English in the original text] into which I was born. I had to disseminate it so that it could become a tiny protein in that code that would have broken the chains of oppression. (p. 129)

\section{Horizon Lost}

These three books obviously do not exhaust the experience of the contemporary Italian working class. They cover extensive ground in terms of industries and circumstances, but, for one, all are written by white men, so they are not representative of the lived reality of women and immigrants-just two important subjects that come to mind when discussing Italy's mondo del lavoro. Yet, they are enough to give us a glimpse of what it means to belong to the working class in Italy today. First, what these books reveal is a shared trauma of generational loss. Trevisan, Falco, and Prunetti were born in the 1960s and 1970s, so their adult life has coincided with deep transformations in Italian society, including the transition from a labour market that emphasised permanent employment and stability for many to one in which 'flexibility' has become paramount. Having lived through the final throes of the old employment model, they feel the pangs of its disappearance strongly, even when they profess contempt for it. This holds true for 
the following generations as well, albeit for those born in the 1980s and later (including myself), precarity was the norm from the outset.

I can write by direct experience here. Like the three authors, I also come from a working-class family. I have memories of my father waking early in the morning to prepare his coffee and drive off to the railway. He started young as an ordinary worker and, over the decades, slowly rose through the ranks of the Italian state railway, eventually retiring a few years ago as the manager of a branch line. He rarely missed a day of work: from Monday to Friday, he would leave home at 6.45 am and return after $5 \mathrm{pm}$. The salary was not high, but the job was stable, the contributions to social security and the pension were assured, and there were perks such as the opportunity to take any train for free-a privilege of which I also could partake until I turned eighteen. As the son of a working-class family, I remember all the uncertainty when the time came to choose what to do after middle school. No-one in my family had attended university, and the priority then was to choose a path that would land me a good job. I remember seriously considering a vocational school specialised in advertising, but I eventually chose to go to a high school with a strong focus on the classics that entailed a commitment to attend university to be placeable in the labour market. It was not a foregone conclusion and for a long time I questioned my decision.

As I entered university in the early 2000s, agencies for temporary employment had started popping up everywhere in Italian cities. Again, instead of thinking of my employability, I chose to study Chinese language at a time when this was not a fashionable choice, and eventually ended up being sucked into a subsection of il mondo del lavoro different to that described by the three authors discussed in this essay-that of il lavoro di cultura ('the work of culture'). While the level of physical exertion is obviously very different from that of a tinsmith, warehouse worker, or kitchen hand, what the world I found myself in has in common with the mondo del lavoro at large is its extreme precariousness, the prevalence of contracts that last no more than two or three years, the toxicity of workplaces dominated by neoliberal logics pursued by corporate hacks with intellectual pretences, with the additional bonus of having to often relocate from one continent to another. While that of the neoliberal university is a story I have written about elsewhere (see Franceschini 2021), in circumstances like these, just like Trevisan, Prunetti, and Falco, I cannot but compare my situation with that of my father, and his father before him, and wonder whether at some point something went seriously wrong in the way we imagine our society and the roles we play in it.

These books also reveal a general loss of horizon. The three memoirs are highly pessimistic and, despite the best efforts of the authors to be ironic and detached, the tone often borders on desperation. For Trevisan and Falco, the only path to deliverance can be found in the act of writing, in the opportunities that being acknowledged as writers provide them. However, few people have the skills to become a successful writer, not to mention that writing is a highly individualistic action that, in itself, does not offer a collective way forward. Only Prunetti, after his epiphany in the Turkish restaurant, comes to conceive of writing as a way to challenge the Lovecraftian horror of capitalism-an agenda he continues to pursue to this day by editing and promoting working-class literature for a leftist publisher in Italy. However, even in Prunetti, the general feeling is pessimistic. Even admitting that change is possible, it will take generations to make it happen: working-class heroes today are nothing but workers who can take a good beating and then still get up, and the best you can do for the time being is to have a good laugh by tricking your boss into rummaging in garbage bins.

Finally, the three books challenge the idea of the ineffability of the working-class condition. While the difficulties to convey in words the working-class experience raised by George Orwell are still there, the three authors did not infiltrate the working class as intellectuals trying to raise the class consciousness of workers or as sociologists trying to understand worker subjectivities; they are true members of the working class and still manage to beautifully translate their experiences on the written page. It is true that, as Ottiero Ottieri warned, their education and artistic bent 
set them apart from their colleagues and occasionally made them feel like outsiders, but they nonetheless remain reliable narrators of what it means to be a worker in Italy today. And what they bear witness to is the fact that, as Trevisan writes, the working class of today is a far cry from the caricature that actual outsiders like us often have in mind. Just like the French workers in the nineteenth century described by Jacques Rancière, they are full of surprises: they love luxury, have little or no class consciousness, and often vote for the latest right-wing or populist politician. Most importantly, these working-class authors tell us that workers have been deprived of political imagination, of the very ability to conceive a different future in which their labour is valued, in which the workplace is not a lawless jungle, and in which they do not have to constantly worry about their own future and be ready to cut their neighbour's throat to survive. If anything, the effable workers of the twenty-first century expose this loss of horizon for everyone to see. 
This text is taken from Made in China Journal: Volume 6, Issue 3, 2021, edited by Ivan Franceschini, Nicholas Loubere and Shui-yin Sharon Yam, published 2022 by ANU Press, The Australian National University, Canberra, Australia.

doi.org/10.22459/MIC.06.03.2021.18 